\title{
HYDROGRAPHIC SURVEYS OFF PLYMOUTH IN 1959 AND 1960
}

\author{
The Plymouth Laboratory \\ (With Text-figs. I-I I)
}

By F. A. J. Armstrong And E. I. Butler

The physical and chemical properties of sea water in the English Channel have been studied for the last 70 years (Dickson, 1892; Kyle, 1903; Matthews, 1905, I909, I9I I ; Jee, I919, I920, 192I ; Atkins, $1923 a, b, 1925,1926 a, b, 1928$, 1930, 1953; Harvey, 1923, I925a-c, 1930, 1934; Lumby, I923, 1924, 1935; Cooper, I933a-c, 1938, I958, 1960; Armstrong \& Atkins, I950; Armstrong \& Harvey, I950; Armstrong, 1954, 1955, 1957 $a, b, 1958 a, b$; Armstrong \& Butler, 1959, 1960 $a, b, 1962$; Armstrong \& Boalch, 196I). The movement of the water has been investigated directly with drift bottles and current meters (Garstang, 1898; Carruthers, 1924, 1926，1930, 1934, 1935; Carruthers, Lawford, Veley \& Gruning, I95I), or by indirect methods (Gehrke, I907; Dietrich, I950, I95I ; Cooper, I960 $a, b$ ). These investigations have shown that water of high salinity enters the western end of the English Channel from the Atlantic Ocean and flows eastward through the Straits of Dover into the North Sea. The inflow of Atlantic water appears to be intermittent, and the variability of the salinity at the mouth of the Channel is probably a consequence of variable water movements in the East Atlantic. A suggestion by Le Danois (1923) that Atlantic water at the mouth of the Channel was replaced in 1922 and 1923 by water from the Irish Sea is unlikely in view of the high salinities observed up channel in those years (Harvey, 1925a). Harvey calculated from the rate of movement of high-salinity water that its movement was $\mathrm{I} \cdot 2$ miles per day in 1908 and I. 6 in I92I. Carruthers (1924) found a rate of I. 5 miles per day from bottom-trailing drift bottles released in mid-channel in 1923. However, water movement may be very variable. Current measurements at the Varne Light Vessel near Dover (Carruthers, 1935) have shown that they are constant neither in speed nor direction and the easterly movement may be halted or temporarily reversed by strong winds.

The Plymouth Laboratory is conveniently placed for work at the western end of the English Channel, and quite early in the century effort was being concentrated on a few fixed positions which had been designated as International Hydrographic Stations after being first worked by Matthews in 1902. In particular, station $\mathrm{E}$ I at $50^{\circ} \mathrm{O} 2^{\prime} \mathrm{N}$., $4^{\circ} 22^{\prime} \mathrm{W}$., which was 22 miles out, could be reached from Plymouth, several hours' work done and the return to port made in one day. Atkins did much of his work on nutrient elements and 
on the penetration of light into sea water at this position in this manner. A survey of his in 1924 showed that phosphate concentrations over a large area at the mouth of the Channel were fairly uniform and that station E I might be taken as typical of a large area. Atkins therefore worked the station as regularly as he was able, and regular work has been continued by others at the Plymouth Laboratory. Records of salinity and temperature at station E I go back to I902, and of phosphate and silicate to I92I and 1922 respectively. Other chemical work has been done from time to time such as determinations of nitrate (Harvey, 1926, 1928); nitrate, nitrite, ammonia, oxygen, excess base, carbon dioxide (Cooper, I933a-c); total phosphorus (Harvey, I948; Armstrong \& Harvey, 1950); suspended matter (Armstrong \& Atkins, I950; Armstrong, I958b); iron (Armstrong, 1957b); ultra-violet absorption (Armstrong \& Boalch, I96I).

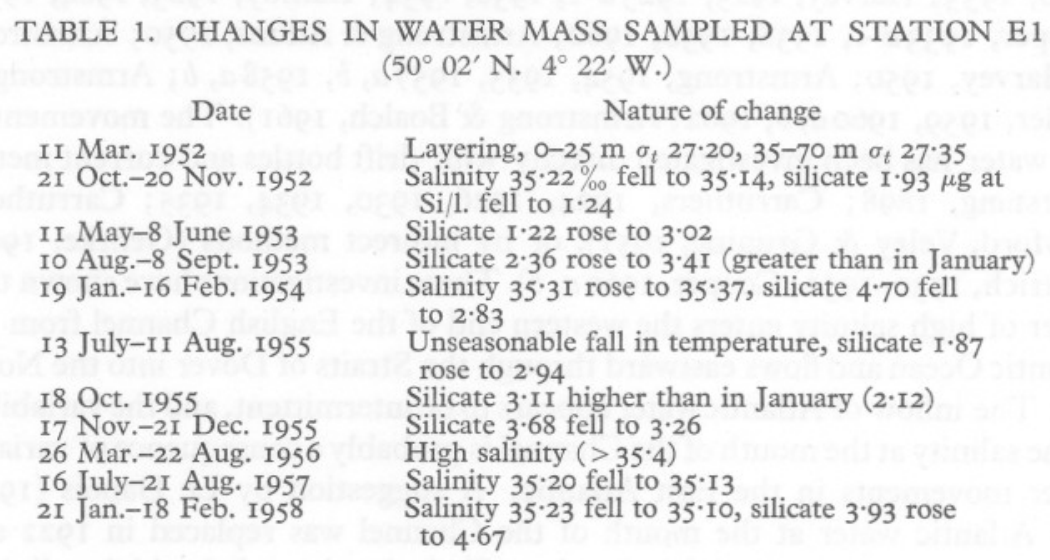

Some of the observations over periods of a few years have been summarized (Atkins, 1953; Cooper, 1938; Southward, 1960), though this is not easy because of the unavoidable irregularity of sampling.

That station E I is not necessarily typical of the western end of the Channel appeared in a survey of 1947 , when quite large variations in phosphate were found (Cooper, I958). Since 1947 the reliability of phosphate determinations was improved as a result of an investigation into the method and the use of a photoelectric absorptiometer (Harvey, 1948). An improved method for silicate was put into use in 1950 (Armstrong, 195I), and it also became possible to work the station at more regular intervals. Before long it could be seen that fluctuations in the properties of water sampled at the station were occurring because of changes in the water mass. Some examples are given in Table $\mathrm{I}$. If the rate of water movement at this station is I or 2 miles per day, it follows that quite large differences in the properties of the water may be found over distances of 20 or 30 miles. It was decided therefore to survey an 
area about 30 miles square to see what degree of non-uniformity existed in it. In 1959 two cruises, one in winter and one in summer, were undertaken. These gave such interesting results that six more cruises were done in 1960. It was hoped that these cruises would serve two purposes: to show to what extent results at station $\mathrm{E}_{\mathrm{I}}$ were typical of the adjacent area, and also to give information on the hydrography of a part of the English Channel of interest to biologists at the Plymouth Laboratory. These cruises supplement the routine monthly cruises to station $\mathrm{EI}_{\mathrm{I}}$, the results from which are reported separately (Armstrong \& Butler, I960 $a, b, \mathrm{I} 962$ ).

In planning the survey we wished to be able to complete the sampling rapidly so that a synoptic view could be obtained and also arrange if possible that the distance between stations was greater than the probable movement of the water by tides and currents. These aims were fulfilled, we think, by taking an area which could be covered in 2 days, and by spacing the stations more than 5 miles apart. This spacing follows from the tidal information in Admiralty Chart I598, which indicates that in the south-western corner of the area (chart position I4) water movement at spring tides would be just under 5 miles. When steaming round a network of stations on a zig-zag course it is very likely that adjacent positions will be worked at one or more multiples of half a tidal period. In the network chosen, stations were fixed at intervals of Io' of latitude or longitude, which are Io and $6 \frac{1}{2}$ sea miles respectively. Tidal movement, at least at spring tides, is not therefore negligible, and introduces some distortion into the isotherms and isohalines which we have drawn in our diagrams as if the stations were sampled simultaneously. We do not think that this distortion is important. A further very slight possible distortion is caused by other movement of the water during the 2 days taken on the cruise.

In order to restrict the number of chemical analyses and also to simplify the presentation of the results, three depths only were sampled. Since nutrient determinations at the surface are neither very reliable nor interesting only temperature and salinity were measured at that level. Nutrient determinations were done at 10 and $50 \mathrm{~m}$, which were supposed, in this area, to be sufficiently representative of the epi- and hypothalassa. The depth of water varies from about $55 \mathrm{~m}$ at the north-east corner to $85 \mathrm{~m}$ at the south-west, and shelves downward gently to the south-west.

\section{WORKING METHODS}

Navigation was by the 'Decca' system so that the positions of stations were probably accurate to $\pm 0 \cdot \mathrm{I}$ mile. Steaming time between stations was about $\mathrm{I} h$. The time taken for the January 1959 survey (2I stations) was $25 \mathrm{~h}$. The subsequent cruises (32 stations) took about $40 \mathrm{~h}$. The route through the stations was as indicated in Fig. I, except in March 1960 when the network was worked after a cruise to the westward and was entered at the south-west corner. Stations were then worked on a 
zig-zag route going east along the $49^{\circ} 40^{\prime}$ parallel, west along $49^{\circ} 50^{\prime} \mathrm{N}$., east along $50^{\circ} 00^{\prime} \mathrm{N}$., and west along $50^{\circ} \mathrm{ro} \mathrm{O}^{\prime} \mathrm{N}$.

Surface temperature and a sample for salinity were taken with a towed sampler (Lumby, 1927, 1928) which was hauled inboard just as the ship stopped at each station. Temperatures and samples for analysis were taken at 10 and $50 \mathrm{~m}$ with reversing bottles (with paired protected reversing thermometers) on a single hoist. In summer, a bathythermograph was attached to the hydrographic wire just below the $50 \mathrm{~m}$ bottle. The ship was stopped for $10-15 \mathrm{~min}$.

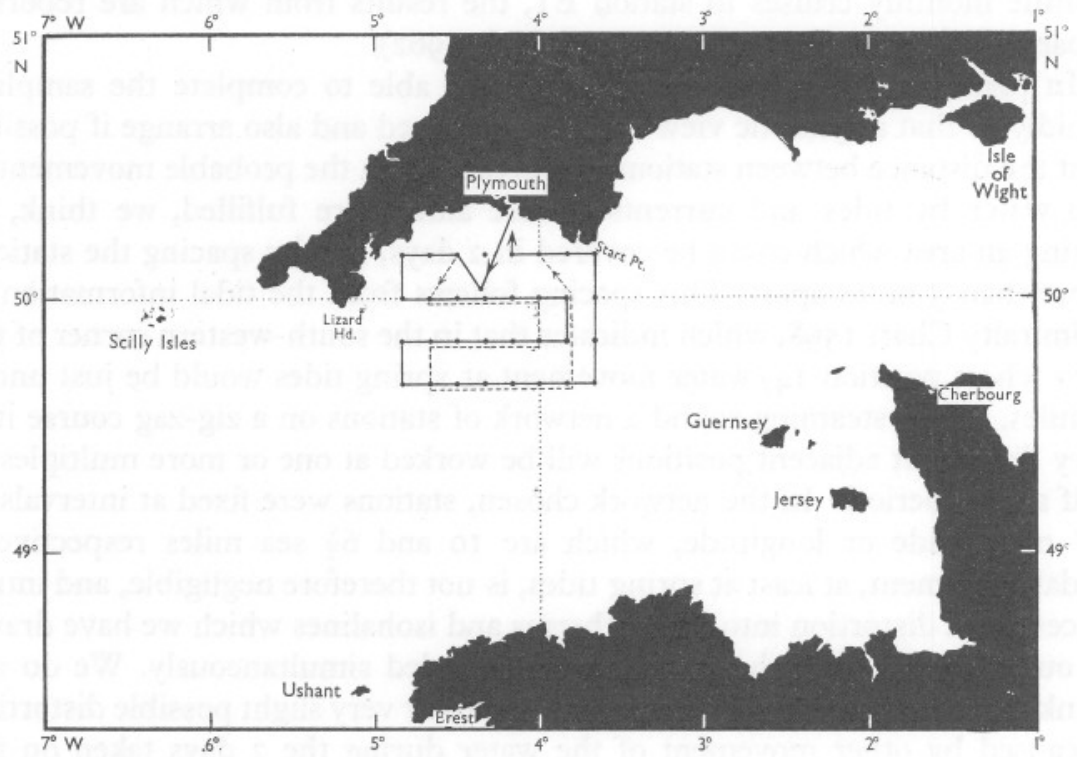

Fig. I. Western end of English Channel, showing area surveyed.

Salinities were determined until July 1960 by chlorinity titration by the Government Chemist, Department of Scientific and Industrial Research. From that time onward, they were done in this laboratory by electrical conductivity, using the National Institute of Oceanography thermostat salinity meter. Phosphate and silicate were determined by molybdenum blue methods. Phosphate samples were preserved with chloroform and kept in a cold store until they could be analysed. Analyses were usually completed within $72 \mathrm{~h}$. of collection of samples.

\section{RESULTS}

The eight cruises which were made started on I3 January and 24 June I959, and 4 January, 9 March, 4 May, 6 July, I I October and 20 December I960. It is hoped that the detailed results will appear in the Bulletin Hydrographique of the International Council for the Exploration of the Sea. The presentation here is graphical and we have omitted some of the winter results when differences at the three depths were negligible, and some of the summer 
nutrient values which are so low as to make it difficult to draw meaningful contours.

Fanuary 1959 (Figs. 2, 3)

Observations for this cruise are given in full in order to show their reliability and the good agreement which can be obtained between sets of measurements. The isothermals run roughly east and west with the southern part of the area about $\mathrm{I}^{\circ} \mathrm{C}$ warmer than the coastal part. Salinity, density, phosphate and silicate all show a tongue of water projecting south-eastward from station E I, and readily distinguishable by its lower salinity and higher phosphate and silicate contents. These properties suggest that it contains land-drainage water, and the south-easterly extension may indicate that this mass of water may be pushed eastward by general water movement in the area, being banked against the slope of the bottom and elongated. The dotted line on the density diagrams show the 40 -fathom contour taken from the chart. A rough calculation shows that to lower the salinity in the area to the values shown would require a rainfall of about $20 \mathrm{~cm}$ in the catchment area of the rivers draining into the area.

\section{fune I959 (Figs 4, 5)}

The isotherms run mostly north and south, and at $\mathrm{o}$ and $\mathrm{ro} \mathrm{m}$ the water to the west is $2^{\circ} \mathrm{C}$ warmer than to the east. Temperature gradients are very steep in places. At $50 \mathrm{~m}$ the warmer water is to the east, the difference being about $\mathrm{I} \cdot 8^{\circ} \mathrm{C}$. This reversal of gradients is a consequence of the mixing process which, it is evident, occurs as the incoming water crosses the area. It appears that warm water of high salinity is entering the north-west corner near Lizard Point, with well marked layering giving a thermocline at $20 \mathrm{~m}$. As this water moves across the area mixing takes place and the thermocline becomes more shallow and the temperature of the bottom water rises. Phosphate concentrations were too low to draw useful diagrams but those for silicate are given. They show, to the west, lower silicate in the upper layers, and to the east, the vertical homogeneity caused by mixing.

Fanuary I960 (Figs. 6, II)

Results at $10 \mathrm{~m}$ only are shown. The $50 \mathrm{~m}$ observations are very similar; this applies also in March, October and December. Isotherms and isohalines run roughly east and west; there is no sign of the tongue of low-salinity water found in January I959. (There had been very rough weather for 8 weeks before this cruise, with south-westerly gales, and this may have caused lateral mixing in the area.) Phosphate is relatively high throughout the area, with a patch of high-phosphate water surrounding station Er. Silicate is higher near the coast. The temperature and salinity diagrams indicate that warmer more saline water is entering the area from the south-east. 
March 1960 (Figs. 6, II)

Again, isotherms and isohalines run roughly east and west, and high nutrient concentrations are found near the coast. Over much of the area the salinity has increased by about $0.1 \%$ since January.
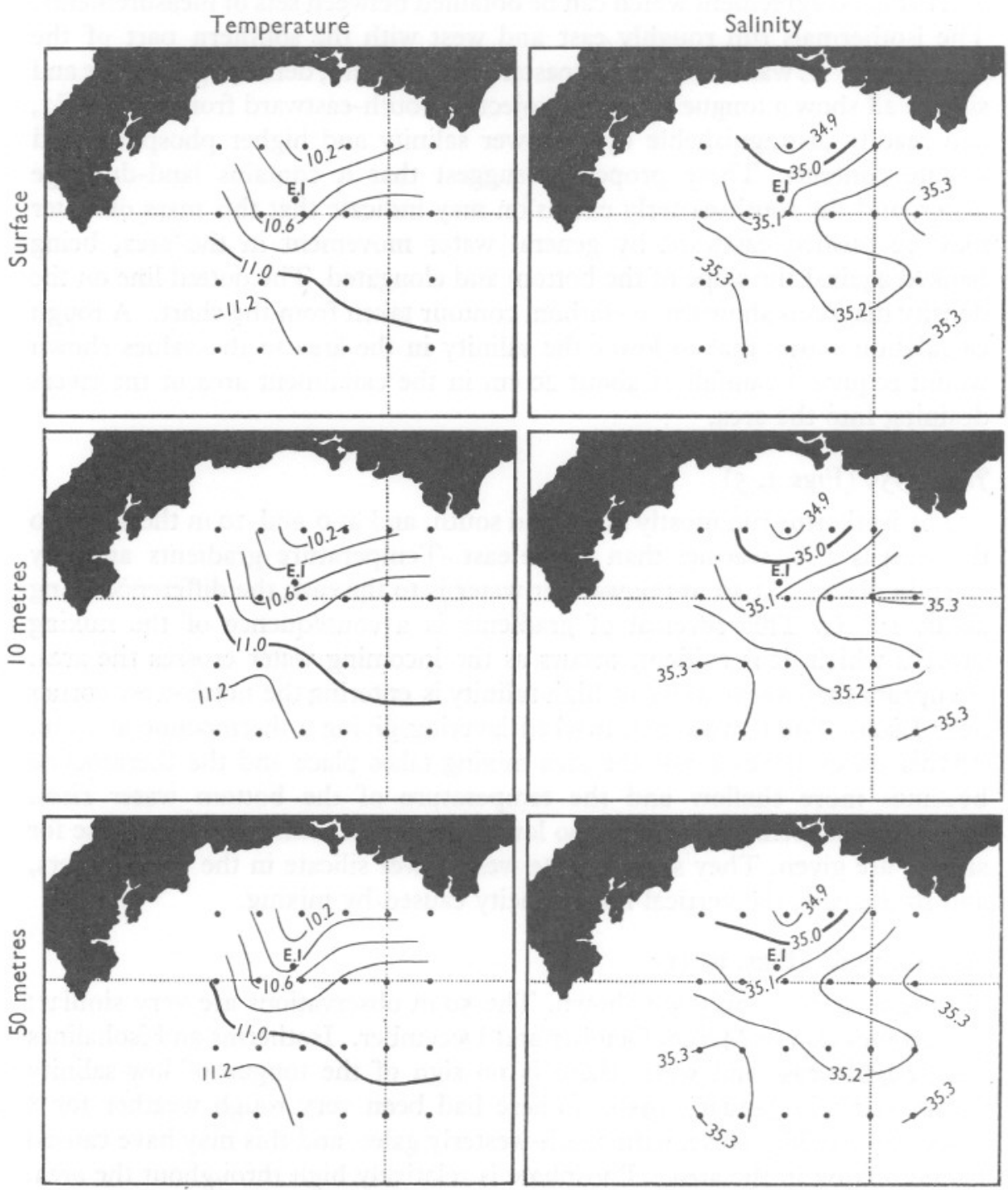

Fig. 2. Temperature $\left({ }^{\circ} \mathrm{C}\right)$ and salinity $(\%)$, January 1959. 

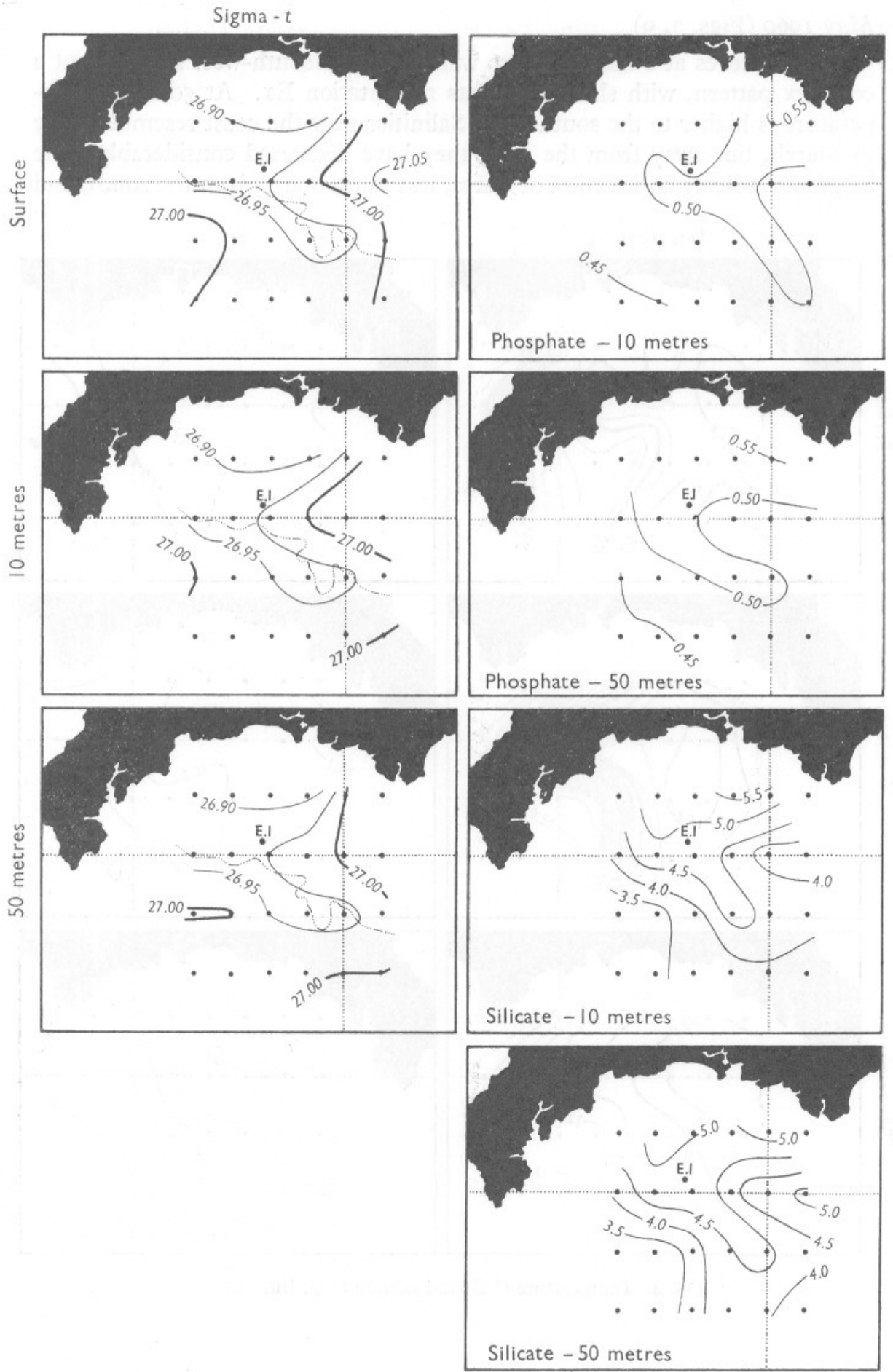

Fig. 3. Density $\left(\sigma_{t}\right)$, phosphate ( $\mu$ gatom $\mathrm{P} / 1$.) and silicate ( $\mu$ gatom Si/1.), January 1959. 
May 1960 (Figs. 7, 9)

Temperatures at $\mathrm{O}$ and $10 \mathrm{~m}$ are warmer to the south-west and present a complex pattern, with sharp gradients near station Er. At $50 \mathrm{~m}$ the temperature is higher to the south-east. Salinities near the coast resemble those in March, but away from the coast they have decreased considerably. The diagrams indicate an invasion of warm, less saline water from the south, and
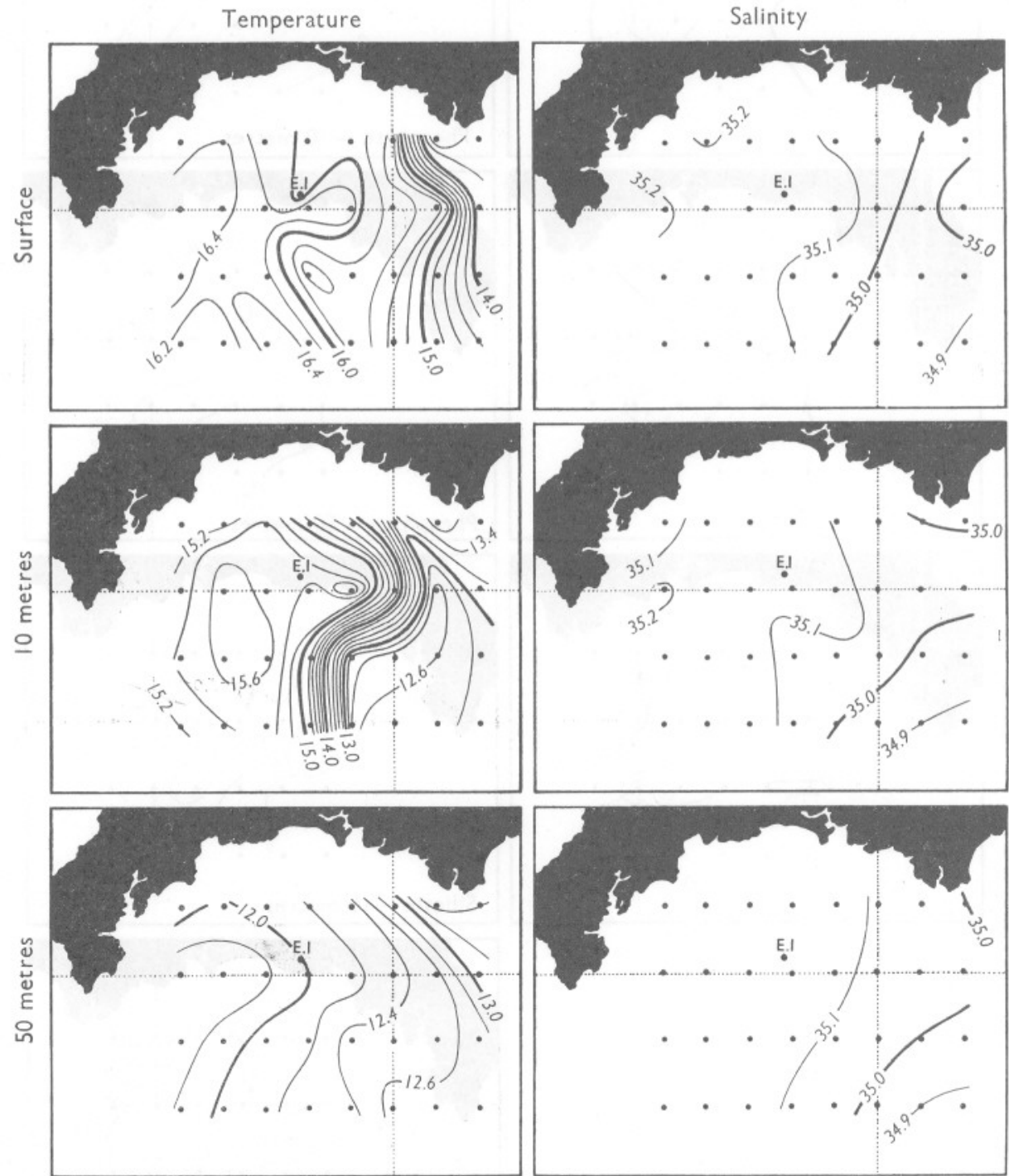

Fig. 4. Temperature $\left({ }^{\circ} \mathrm{C}\right)$ and salinity (\%), June 1959. 
it is difficult to judge whether from the south-west., as is suggested by the $\mathrm{O}$ and $10 \mathrm{~m}$ diagrams, or from the south-east as by the $50 \mathrm{~m}$ one. The distribution of densities suggests a movement towards the south-east. As would be expected from the irregular temperature contours, particularly at Io $\mathrm{m}$, the depth of the thermocline was very irregular, which suggests some vigorous mixing process. It was somewhat deeper to the west of the area.
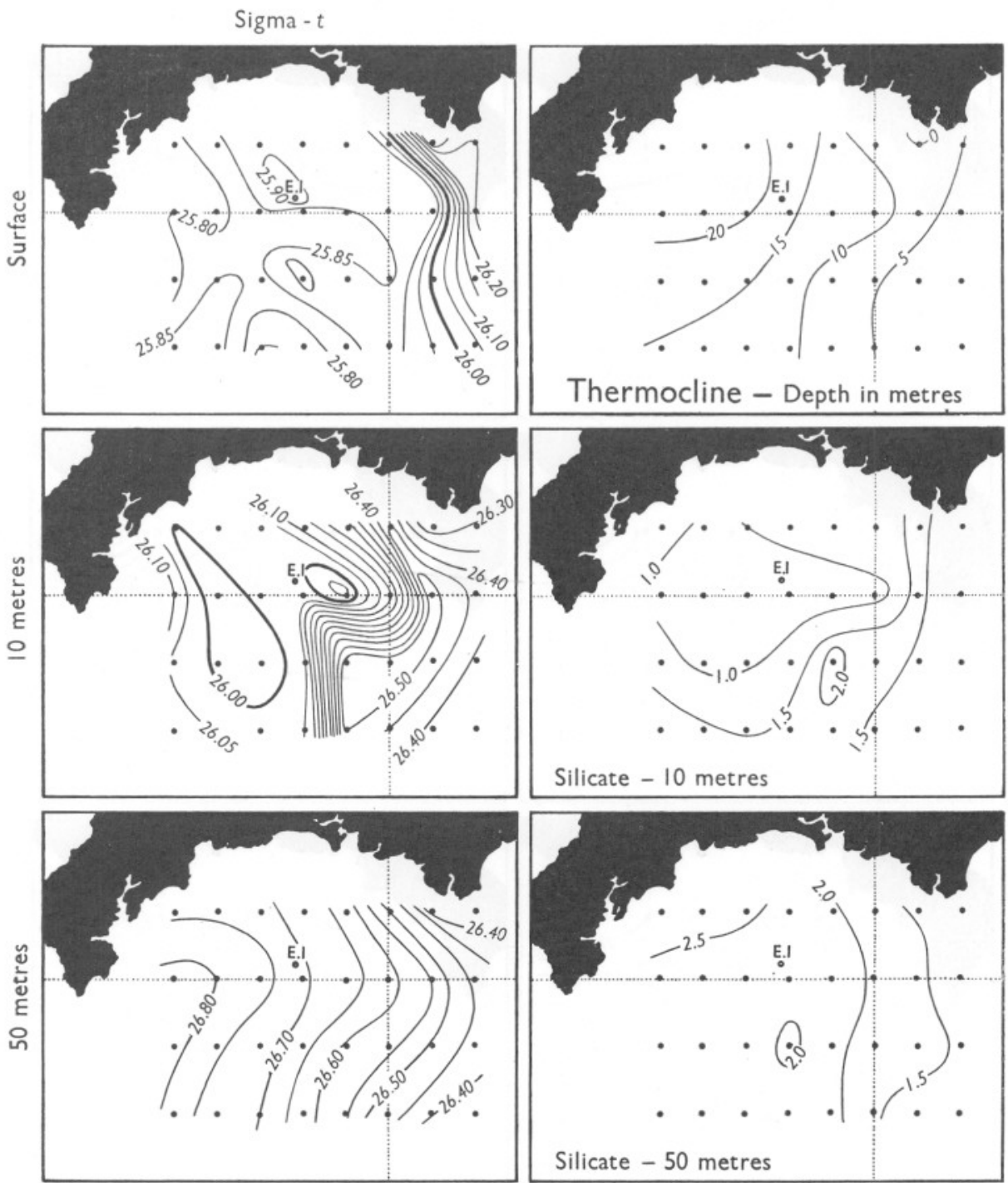

Fig. 5. Density $\left(\sigma_{t}\right)$, depth of thermocline (m) and silicate ( $\mu$ gatom $\mathrm{S}_{1} / 1$.), June 1959 . 
Phosphate values were quite low (from 0.08 to $0.22 \mu \mathrm{g}$-atom $\mathrm{P} / 1$.) in the upper layers.

fuly 1960 (Figs. 7, 10)

Temperatures were highest to the west, at $\mathrm{O}$ and $\mathrm{Io} \mathrm{m}$, and to the east at $50 \mathrm{~m}$. Salinities are slightly lower than in May, and there is an intruded band of water of salinity reaching in a north-westerly direction from the
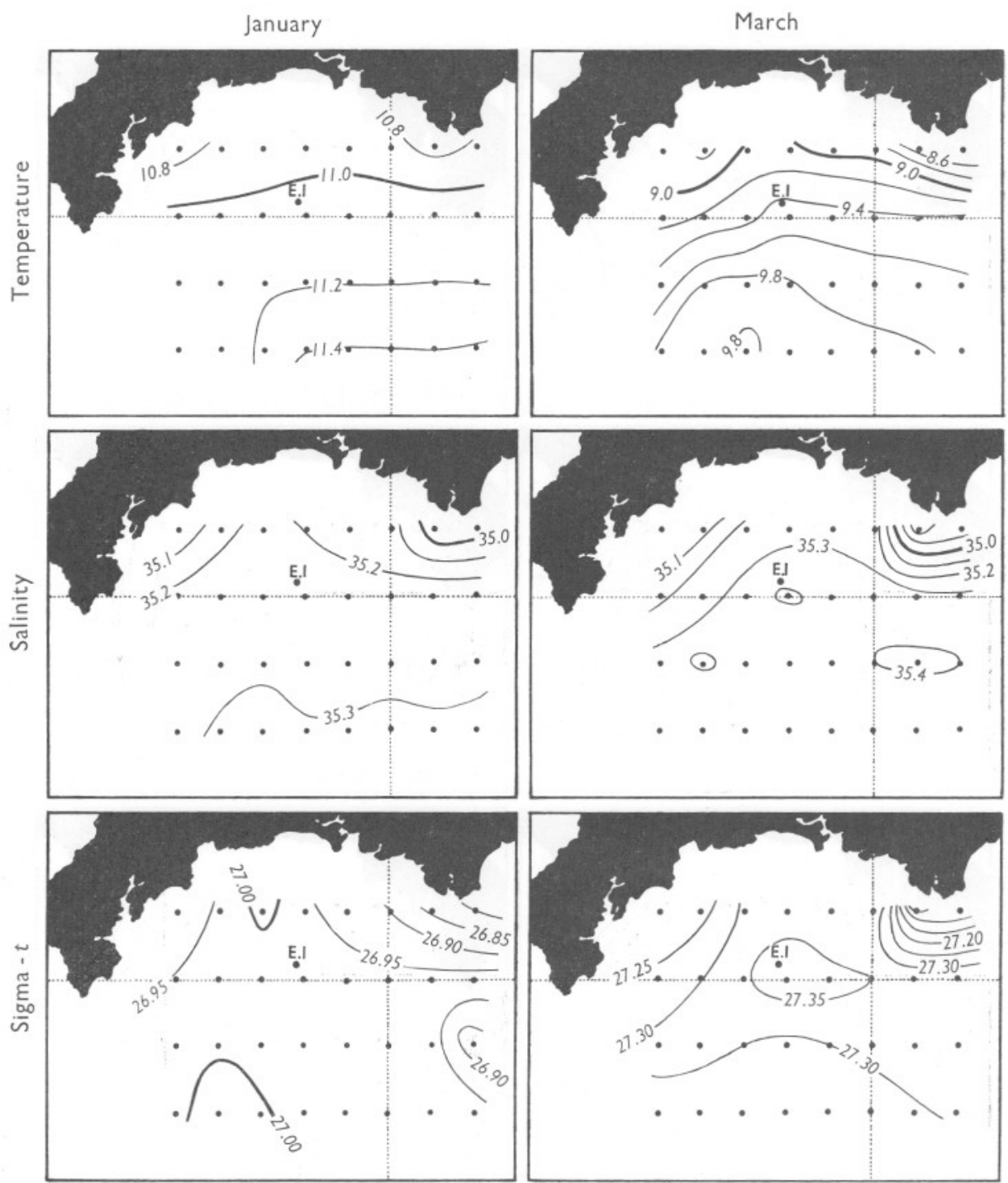

Fig. 6. Temperature, salinity and density at $10 \mathrm{~m}$, January and March 1960. 
south-eastern corner where values of less than $34 \cdot 7 \%$ were found. The depth of the thermocline was about $20 \mathrm{~m}$ over the whole area except the northeastern corner near Start Point. Nutrient levels were low over the whole area.

October 1960 (Figs. 8, II)

Vertical mixing had occurred over the whole area and the Io $\mathrm{m}$ values are typical of all depths. The lowest temperatures were found offshore. Low-

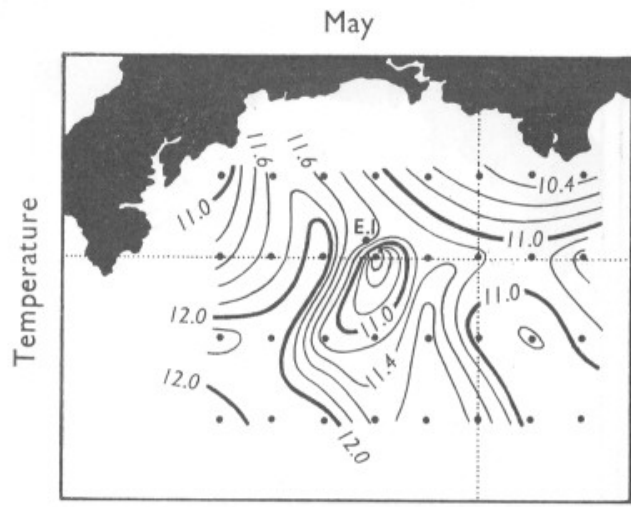

July
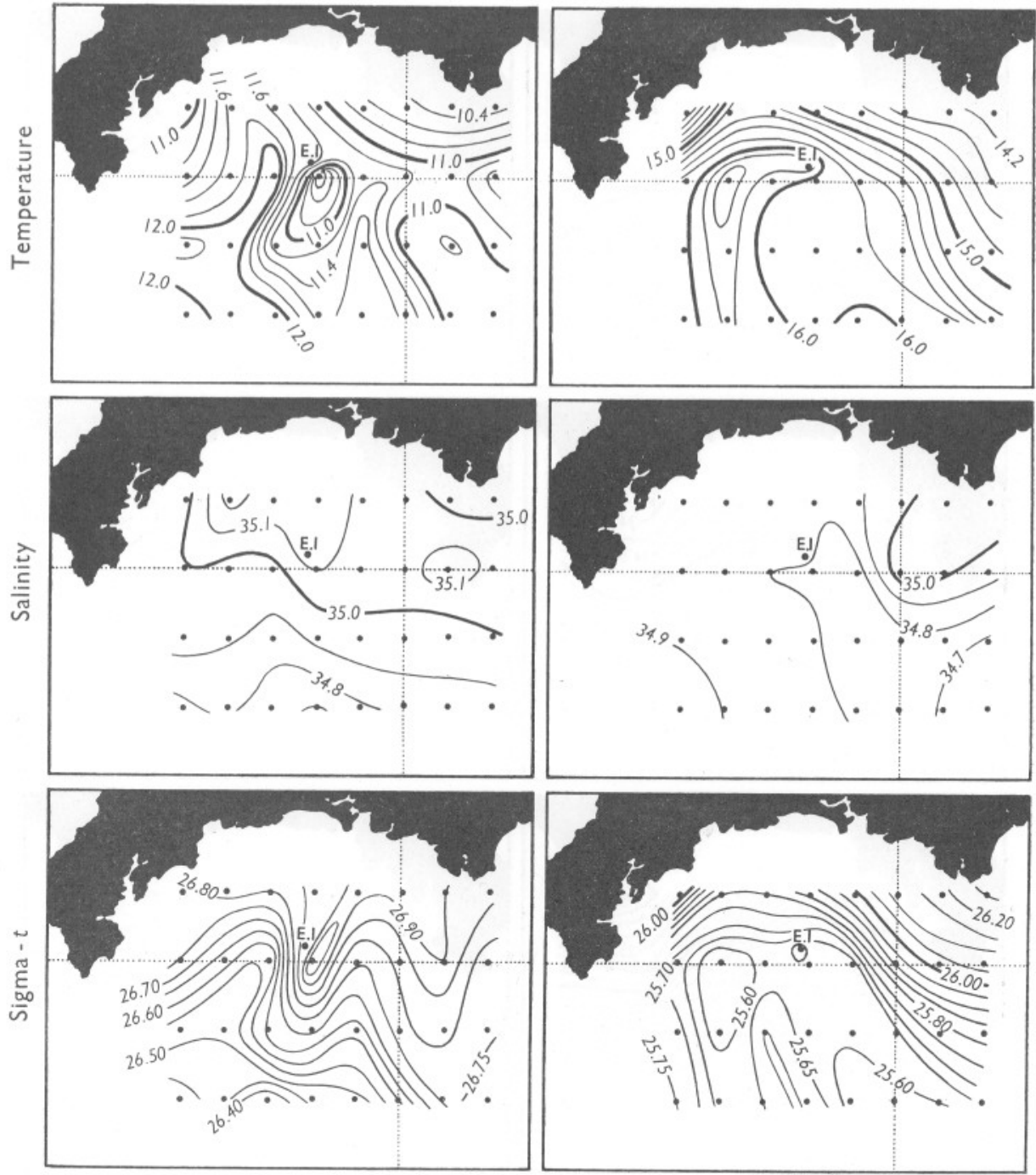

Fig. 7. Temperature, salinity and density at ro m, May and July r960. 
salinity water is found near the coast, but farther offshore the low-salinity water had been replaced by other of much higher salinity which appeared to enter from the south-west. The density gradients indicate a flow in to the east.

\section{December 1960 (Figs. 8, II)}

Temperatures have fallen considerably and are now highest offshore, where again, the highest salinities are found. As a result maximum density
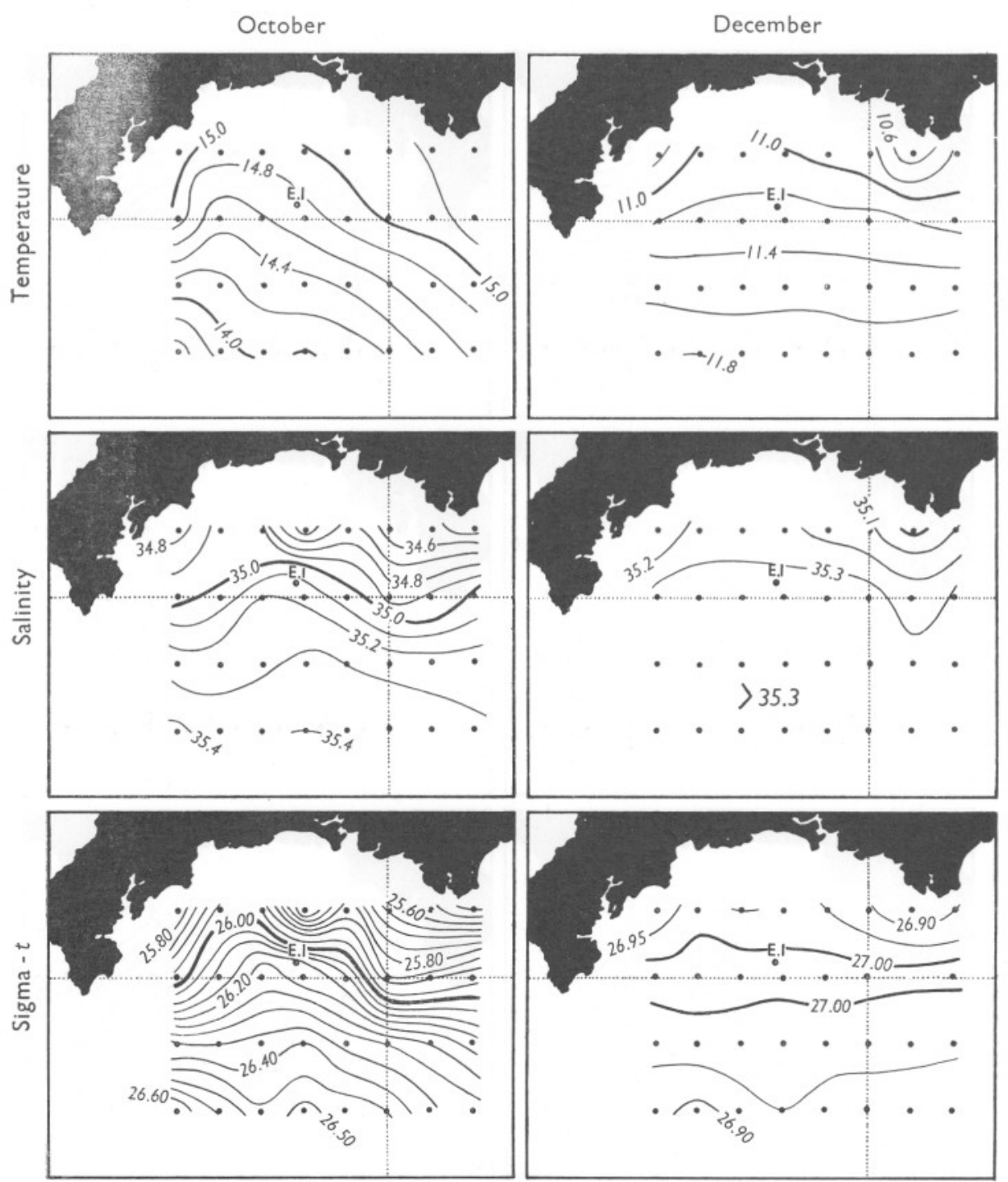

Fig. 8. Temperature, salinity and density at Io m, October and December I960. 
occurs in a band offshore, lying east and west. Currents would therefore be expected to run westward near the west and eastward along the southern part of the area.

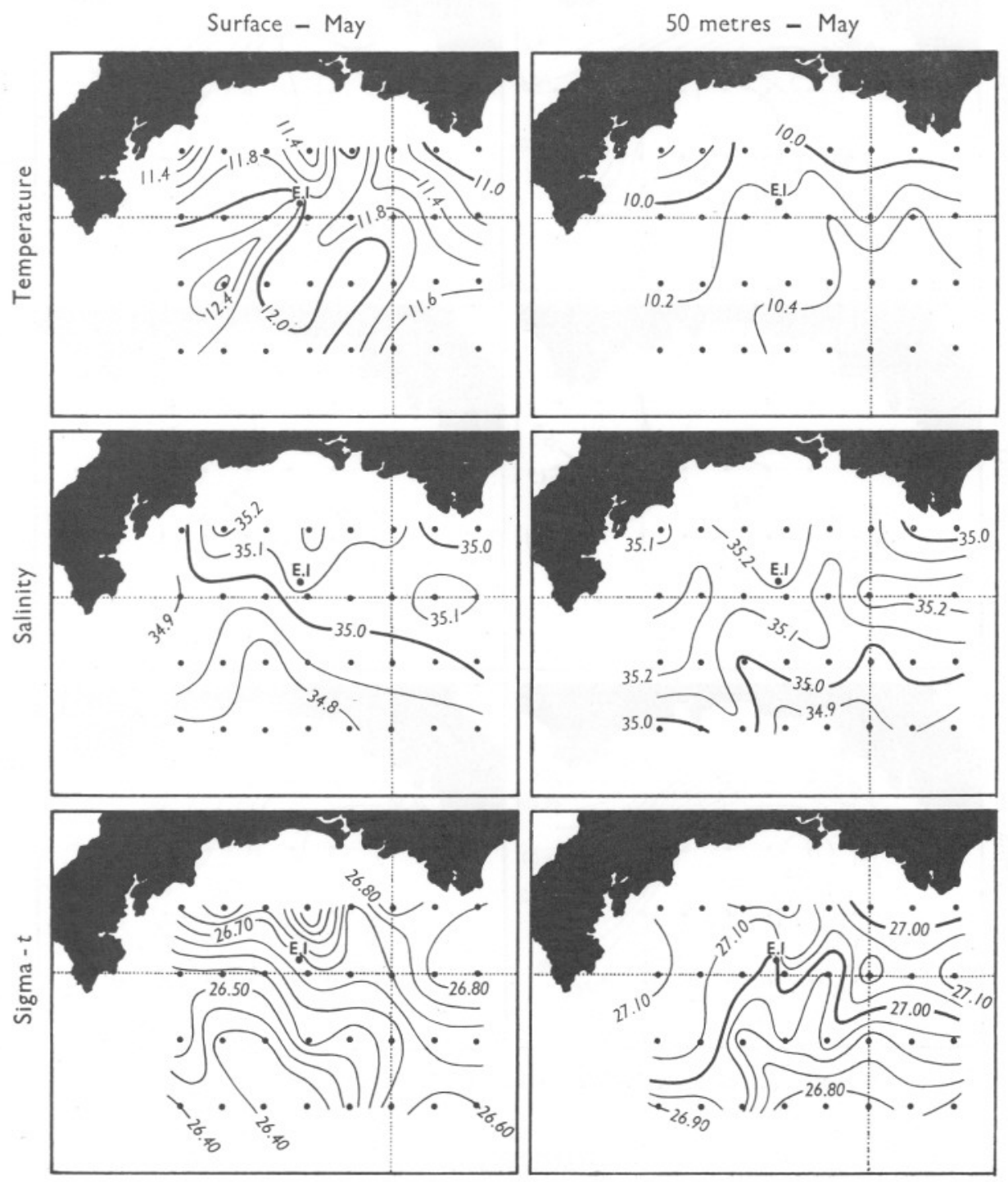

Fig. 9. Temperature, salinity and density at $\mathrm{o}$ and $50 \mathrm{~m}$, May 1960. 

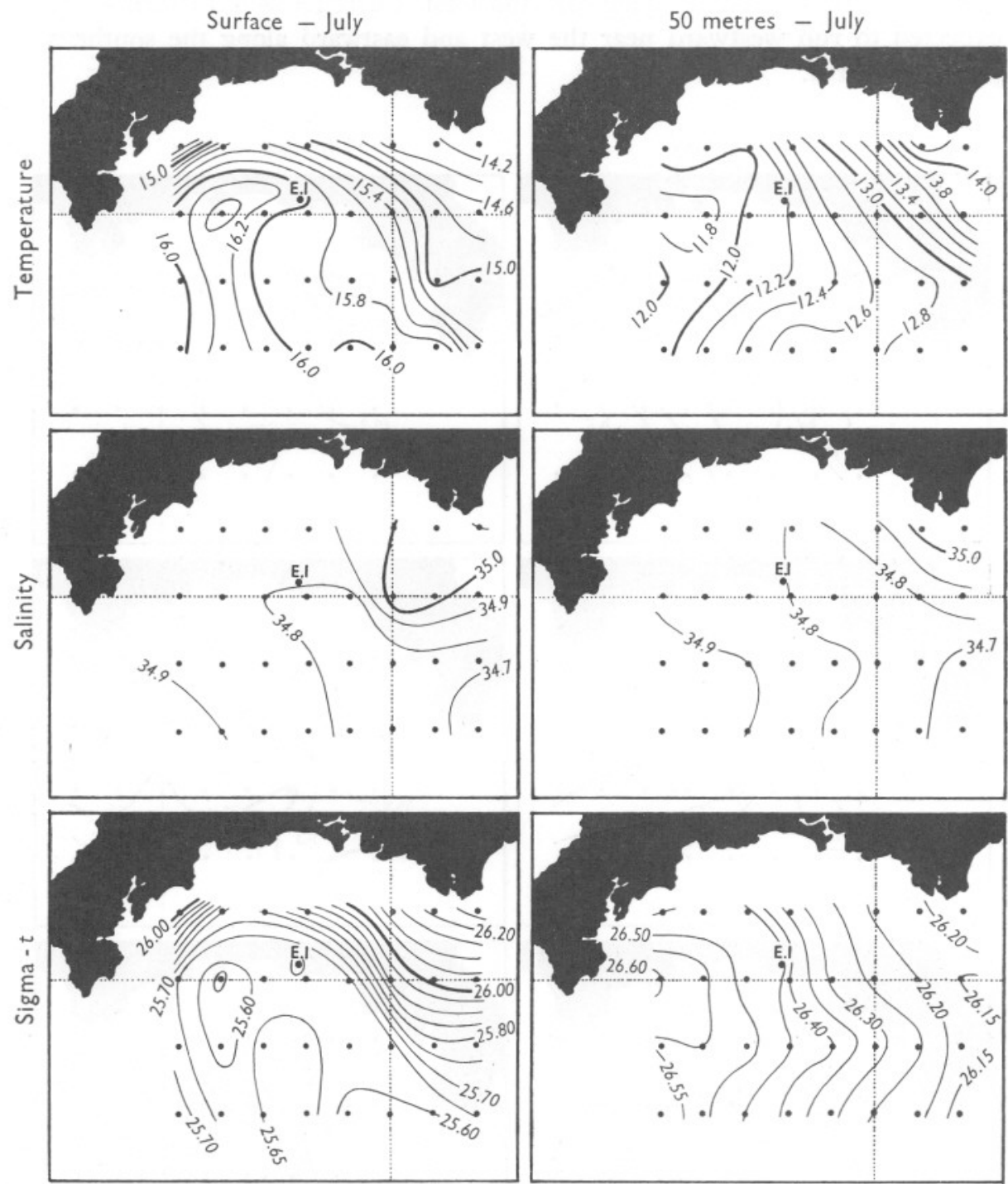

Fig. Io. Temperature, salinity and density at o and $50 \mathrm{~m}$, July I960.

\section{DISCUSSION}

It is at once apparent that even in so small an area as this there are quite large differences from place to place, and that surveys at intervals of 2 months are too infrequent to allow one to trace water movements. It is obvious that station $\mathrm{E}_{\mathrm{I}}$ is often surrounded by water of rapidly changing characteristics 
Phosphate
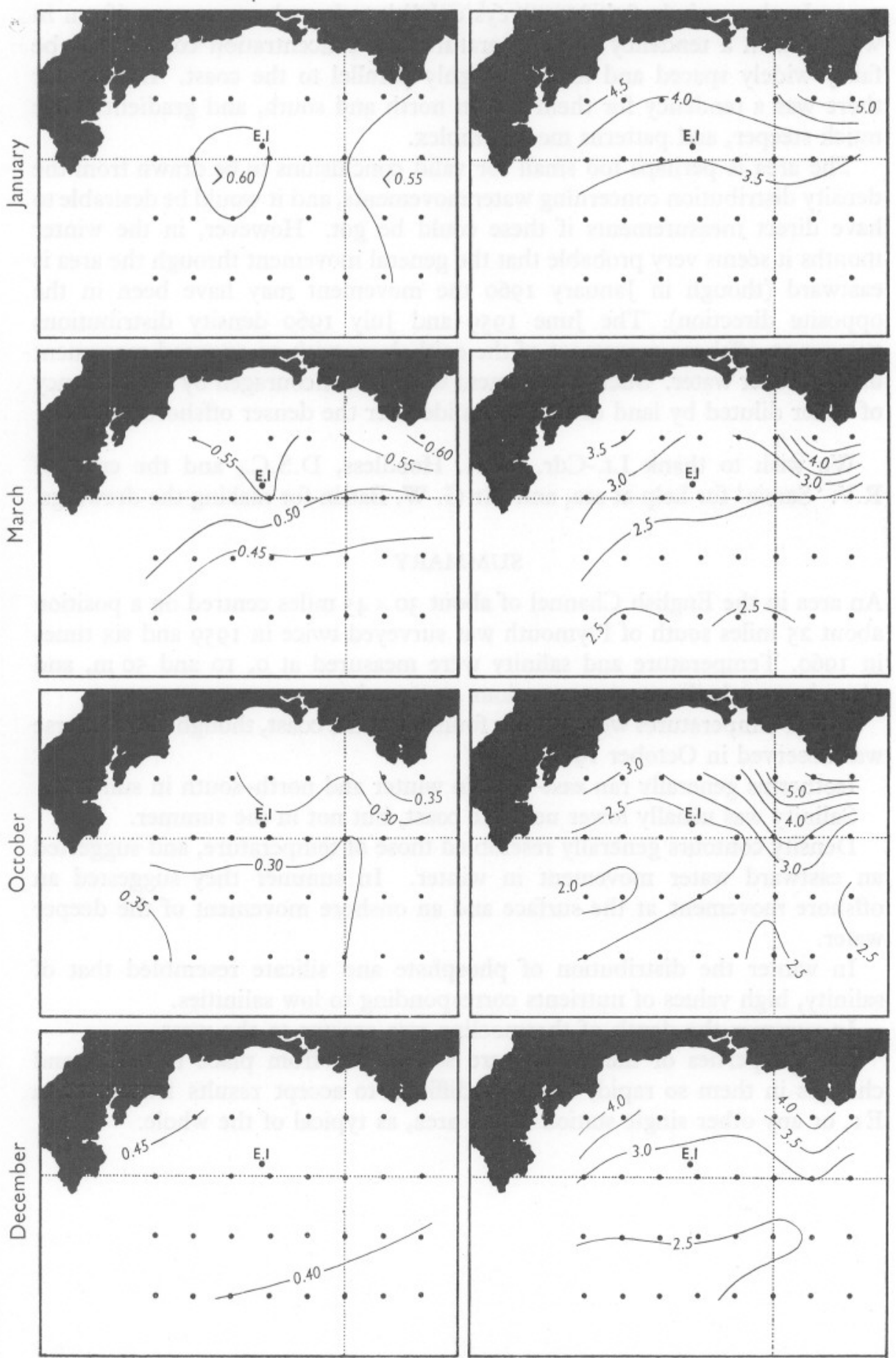

Fig. II. Phosphate and silicate at Io m, January, March, October and December r96o.

Silicate
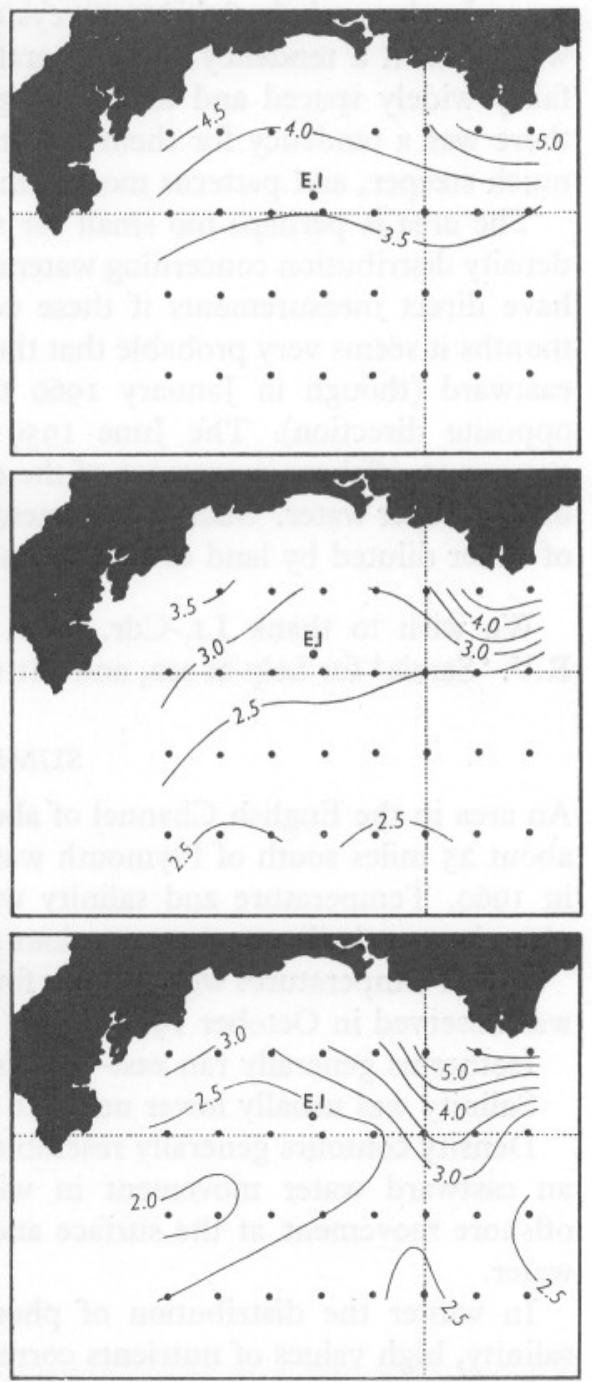
and one is doubtful about accepting results from this station as typical of the area. In the period of these surveys conditions have been more uniform in winter, with a tendency for temperature and concentration contours to be fairly widely spaced and to run roughly parallel to the coast. In summer there was a tendency for them to run north and south, and gradients were much steeper, and patterns more complex.

The area is perhaps too small for valid conclusions to be drawn from the density distribution concerning water movements, and it would be desirable to have direct measurements if these could be got. However, in the winter months it seems very probable that the general movement through the area is eastward (though in January 1960 the movement may have been in the opposite direction). The June I959 and July I960 density distributions suggest an offshore movement of the epithalassa with an opposed movement of the deeper water. Such a movement would be encouraged by the tendency of water diluted by land drainage to slide over the denser offshore water.

We wish to thank Lt.-Cdr. C. A. Hoodless, D.S.C., and the crew of R.V. 'Sarsia' for help at sea, and Mr G. W. Battin for making the drawings.

\section{SUMMARY}

An area in the English Channel of about $30 \times 45$ miles centred on a position about 25 miles south of Plymouth was surveyed twice in 1959 and six times in 1960. Temperature and salinity were measured at 0 , I0 and $50 \mathrm{~m}$, and phosphate and silicate concentrations at 10 and $50 \mathrm{~m}$.

Lower temperatures were usually found near the coast, though the converse was observed in October 1960.

Isotherms generally ran east-west in winter and north-south in summer.

Salinity was usually lower near the coast, but not in the summer.

Density contours generally resembled those of temperature, and suggested an eastward water movement in winter. In summer they suggested an offshore movement at the surface and an onshore movement of the deeper water.

In winter the distribution of phosphate and silicate resembled that of salinity, high values of nutrients corresponding to low salinities.

In summer the depth of thermocline was greater to the west.

The properties of the water were so variable from place to place, and changes in them so rapid, that it is difficult to accept results from station $\mathrm{E}$, or any other single station in the area, as typical of the whole. 


\section{REFERENCES}

ARmstrong, F. A. J., I949. A source of error in the absorptiometric determination of inorganic and total phosphorus in sea water. F. mar. biol. Ass. U.K., Vol. 28, pp. $70 \mathrm{I}-5$.

- I95I. The determination of silicate in sea water. F. mar. biol. Ass. U.K., Vol. 30, pp. 149-60.

I954. Phosphorus and silicon in sea water off Plymouth during the years 1950 to I953. F. mar. biol. Ass. U.K., Vol. 33, pp. 381-92.

I955. Phosphorus and silicon in sea water off Plymouth during 1954. F. mar. biol. Ass. U.K., Vol. 34, pp. 223-28.

- I957 a. Phosphorus and silicon in sea water off Plymouth during 1955. F. mar. biol. Ass. U.K., Vol. 36, pp. 317-19.

- $1957 b$. The iron content of sea water. F. mar. biol. Ass. U.K., Vol. 36, pp. 509-17.

I 1958 a. Phosphorus and silicon in sea water off Plymouth during 1956. $\mathcal{F}$. mar. biol. Ass. U.K., Vol. 37, pp. 37 I-7.

- 1958 b. Inorganic suspended matter in sea water. F. mar. Res. Vol. I7, pp. 23-34.

Armstrong, F. A. J. \& Atkins, W. R. G., I950. The suspended matter of sea water. F. mar. biol. Ass. U.K., Vol. 29, pp. 139-43.

Armstrong, F. A. J. \& BoAlch, E. T., I96I. The ultra-violet absorption of sea water. F. mar. biol. Ass. U.K., Vol. 4I, pp. 59I-7.

Armstrong, F. A. J. \& Butler, E. I., I959. Chemical changes in sea water off Plymouth during 1957. F. mar. biol. Ass. U.K., Vol. 38, pp. 4I-5.

I960a. Chemical changes in sea water off Plymouth during 1958. F. mar. biol. Ass. U.K., Vol. 39, pp. 299-302.

1960 $b$. Chemical changes in sea water off Plymouth during 1959. F. mar. biol. Ass. U.K., Vol. 39, pp. 525-8.

1962. Chemical changes in sea water off Plymouth during 1960. F. mar. biol. Ass. U.K., pp. 253-8.

Armstrong, F. A. J. \& Harvey, H. W., I950. The cycle of phosphorus in the waters of the English Channel. F. mar. biol. Ass. U.K., Vol. 29, pp. 145-62.

Atkins, W. R. G., I923a. The phosphate content of fresh and salt waters in its relationship to the growth of the algal plankton. F. mar. biol. Ass. U.K., Vol. I3, pp. II9-50.

I $1923 b$. The silica content of some natural waters and of culture media. F. mar. biol. Ass. U.K., Vol. 13, pp. I5I-9.

- 1925. Seasonal changes in the phosphate content of sea water in relation to the growth of algal plankton during 1923 and 1924. F. mar. biol. Ass. U.K., Vol. I3, pp. 700-20.

- 1926 a. Seasonal changes in the silica content of natural waters in relation to the phytoplankton. F. mar. biol. Ass. U.K., Vol. I4, pp. 89-99.

I $1926 \mathrm{~b}$. The phosphate content of sea water in relation to the growth of the algal plankton. Part III. F. mar. biol. Ass. U.K., Vol. I4, pp. 447-67.

1928. Seasonal variations in the phosphate and silicate content of sea water during 1926 and 1927 in relation to the phytoplankton crop. F. mar. biol. Ass. U.K., Vol. I5, pp. I9I-205.

- 1930. Seasonal variations in the phosphate and silicate content of sea water in relation to the phytoplankton crop. Part V. November 1927 to April 1929, compared with earlier years from 1923. F. mar. biol. Ass. U.K., Vol. r6, pp. $82 \mathrm{I}-52$. 
AtKIns, W. R. G., I953. Seasonal variations in the phosphate and silicate content of sea water. Part VI. 1948 compared with the 1923-25 period. F. mar. biol. Ass. U.K., Vol. 31, pp. 489-92.

Atkins, W. R. G. \& Jenkins, P. G., I952. Note on sea temperatures in the English Channel I92I to I949, and Plymouth sunshine and light. F. mar. biol. Ass. U.K., Vol. 3I, pp. 327-33.

Atkins, W. R. G., Jenkins, P. G. \& WARren, F. J., I954. The suspended matter in sea water and its seasonal changes as affecting the visual range of the Secchi disc. F. mar. biol. Ass. U.K., Vol. 33, pp. 497-509.

Carruthers, J. N., I924. The water movement of the North Sea in relation to the geographical distribution of post-larval herring. Fish. Invest., Lond., Ser. 2, Vol. 6, No. 4 (Appendix).

- I926. Investigations upon the water movements in the English Channel, Summer 1924. F. mar. biol. Ass. U.K., Vol. 14, pp. 685-721.

- 1930. Further investigations upon the water movements in the English Channel. 7. mar. biol. Ass. U.K., Vol. I7, pp. 24I-75.

- 1934. The flow of water past the Seven Stones Light Vessel. F. mar. biol. Ass. U.K., Vol. I9, pp. 42I-30.

- I935. The flow of water through the Straits of Dover. Fish Invest., Lond., Ser. 2, Vol. I4, No. 4, pp. I-67.

Carruthers, J. N., Lawford, A. L., Veley, V. F. C. \& Gruning, J. F., I95I. Studies of water movements and winds at various light vessels. II. At the Seven Stones light vessel near the Scilly Isles. F. mar. biol. Ass. U.K., Vol. 29, pp. 587-608.

Cooper, L. H. N., r933a. Chemical constituents of biological importance in the English Channel, November 1930 to January 1932. Part I. Phosphate, silicate, nitrate, nitrite, ammonia. F. mar. biol. Ass. U.K., Vol. I8, pp. 677-728.

- $1933 b$. Chemical constituents of biological importance in the English Channel, November 1930 to January 1932. Part II. Hydrogen-ion concentration, excess base, carbon dioxide and oxygen. F. mar. biol. Ass. U.K., Vol. I8, pp. 729-53.

I933c. Chemical constituents of biological importance in the English Channel. Part III. June-December 1932. Phosphate, silicate, nitrite, hydrogen ion concentration, with a comparison of wind records. F. mar. biol. Ass. U.K., Vol. I9, pp. 55-62.

- 1938. Phosphate in the English Channel I933-8 with a comparison with earlier years I9I6 and 1923-32. F. mar. biol. Ass. U.K., Vol. 23, pp. I81-95.

- 1958. Consumption of nutrient salts in the English Channel as a means of measuring production. Rapp. Cons. Explor. Mer, Vol. I44, pp. 35-7.

- I960a. Water flow into the English Channel from the south west. f. mar. biol. Ass. U.K., Vol. 39, pp. 173-208.

I $1960 b$. Exchanges of water between the English and Bristol Channels around Lands End. F. mar. biol. Ass. U.K., Vol. 39, pp. 637-58.

Cooper, L. H. N., LAwFord, A. L. \& Veley, V. F. C., I960. On variations in the current at the Seven Stones light vessel. F. mar. biol. Ass. U.K., Vol. 39, pp. 659-65.

Le DanoIs, E., 1923. Rapport Atlantique r921. Rapp. Cons. Explor. Mer, Vol. 29, pp. $25-8$.

Dickson, H. N., I892. Physical Investigations. f. mar. biol. Ass., U.K., Vol. 2, pp. I59-70 and pp. 272-4.

DieTrICH, G., I950. Die anomale Jahresschwankungen des Warmeinhalts im Englischen Kanal, ihre Ursachen und Auswirkungen. Dtsch. hydrogr. Z., Bd. 3, pp. I84-20I. 
DIETRICH, G., I95I. Influences of tidal streams on oceanographic and climatic conditions in the sea as exemplified by the English Channel. Nature, Lond., Vol. 168, p. 8.

GaRSTANG, W., I898. Report on the surface drift of the English Channel and neighbouring seas during 1897. F. mar. biol. Ass. U.K., Vol. 5, pp. 199-23I.

GeHRKE, J., 1907. Mean velocity of the Atlantic currents running north of Scotland and through the English Channel. Publ. Circ. Cons. Explor. Mer, No. 40 (18 pp.).

HaRVEY, H. W., I923. Hydrographic features of the water in the neighbourhood of Plymouth during the years I92I and I922. F. mar. biol. Ass. U.K., Vol. I3, pp. 225-35.

— 1925a. Hydrography of the English Channel. Rapp. Cons. Explor. Mer, Vol. 37, pp. 59-91.

- 1925 b. Water movement and sea temperature in the English Channel. F. mar. biol. Ass. U.K., Vol. 13, pp. 659-64.

- 1925c. Evaporation and temperature changes in the English Channel. F. mar. biol. Ass. U.K., Vol. 13, pp. 678-92.

— 1926. Nitrate in the sea. F. mar. biol. Ass. U.K., Vol. 14, pp. 71-88.

— I928. Nitrate in the sea. II. F. mar. biol. Ass. U.K., Vol. I5, pp. 183-90.

— 1930. Hydrography of the mouth of the English Channel I925-I928. F. mar. biol. Ass. U.K., Vol. 16, pp. 791-820.

— 1934. Hydrography of the mouth of the English Channel I929-I932. F. mar. biol. Ass. U.K., Vol. 19, pp. 737-46.

— I948. The estimation of phosphate and total phosphorus in sea waters. F. mar. biol. Ass. U.K., Vol. 27, pp. 337-359.

JEE, E. C., I9I9-I920-I92I. Review of the physical and chemical properties of the surface waters of the English Channel. Fish. Invest., Lond., Ser. 3, Vol. I, Parts I-VI.

KYLE, H. M., I903. Notes on physical conditions existing within the line from Start Point to Portland. F. mar. biol. Ass. U.K., Vol. 6, pp. 528-40.

LuMBY, J. R., 1923. The salinity and temperature of the southern North Sea and English Channel during the period 1920 to I921. Publ. circ. Cons. Explor. Mer, No. 80 , pp. I8-3I.

- 1924. The salinity and water movements in the English Channel and Southern Bight during the period 1920-1923. Fish. Invest., Lond., Ser. 2, Vol. 7, No. 7, $37 \mathrm{pp}$.

- 1927. The Surface Sampler, an apparatus for the collection of samples from the sea surface from ships in motion. F. Cons. Explor. Mer, Vol. 2. No. 3, pp. 332-42.

— 1928. Modification of the surface sampler with a view to the improvement of temperature observation. F. Cons. Explor. Mer, Vol. 3, No. 3. pp. 340-50. 1935. Salinity and temperature of the English Channel. Fish. Invest., Lond., Ser. 2, Vol. r4, No. 7, 67 pp.

Matthews, D. J., 1905. Report on the physical conditions in the English Channel 1903. Rep. North Sea Fish. Invest. 1902-3, pp. 289-324.

- 1909. Report on the physical conditions in the English Channel and adjacent waters 1904 and 1905. Rep. North Sea Fish. Invest. 1904-5, pp. 279-345.

I9II. Report on the physical conditions in the English Channel and adjacent waters 1906, with a note on the mean conditions from 1903-1909. Rep. North Sea Fish. Invest. 1906-8, pp. 269-82.

SouthWARD, A. J., I960. On changes of sea temperature in the English Channel. F. mar. biol. Ass. U.K., Vol. 39, pp. 449-58. 